\title{
Priming of Seed: Enhancing Growth and Development
}

\author{
Mampi Debbarma ${ }^{1^{*}}$ and Shubhashree Priyadarshinee $\operatorname{Das}^{2}$ \\ ${ }^{1}$ Department of Seed Science and Technology, Mohanpur-741252, West Bengal, India \\ ${ }^{2}$ Department of Vegetable Science, B.C.K.V., Mohanpur-741252, West Bengal, India \\ *Corresponding author
}

\begin{tabular}{|c|c|}
\hline & A B S T R A C T \\
\hline Kaywards & \multirow{6}{*}{$\begin{array}{l}\text { Seed priming is a pre-sowing treatment which leads to a physiological state that enables } \\
\text { seed to germinate more efficiently. Priming often involves soaking seed in predetermined } \\
\text { amounts of water or limitation of the imbibition time. The imbibition rate could be } \\
\text { somehow controlled by osmotic agents such as PEG and referred as osmopriming. } \\
\text { Halopriming implies the use of specific salts while "hormopriming" relies on the use of } \\
\text { plant growth regulators. A better understanding of the metabolic events taking place during } \\
\text { the priming treatment and the subsequent germination should help to use this simple and } \\
\text { cheap technology in a more efficient way. The general purpose of seed priming is to } \\
\text { partially hydrate the seed to a point where germination processes are begun, but they } \\
\text { would exhibit rapid germination when re-imbibed under normal or stress conditions. A lot } \\
\text { of work has been done on seed priming and results of these studies indicate well the } \\
\text { importance of priming to get a good crop stand in many crops. }\end{array}$} \\
\hline neyworas & \\
\hline $\begin{array}{l}\text { Seed priming, Crop } \\
\text { establishment, }\end{array}$ & \\
\hline $\begin{array}{l}\text { Germination, Seedling } \\
\text { growth and storability. }\end{array}$ & \\
\hline Article Info & \\
\hline $\begin{array}{l}\text { Accepted: } \\
17 \text { October } 2017 \\
\text { Available Online: } \\
10 \text { December } 2017\end{array}$ & \\
\hline
\end{tabular}

\section{Introduction}

High quality seeds play an important role in successful crop production. Rapid germination and emergences are essential for successful crop establishment, for which seed priming could play an important role. Seed priming is a pre-sowing strategy for influencing seedling development by modulating pre-germination metabolic activity prior to emergence of the radicle and generally enhances rapid, uniform emergence and plant performance to achieve high vigour and better yields (McDonald, 2000). During priming, seeds are soaked in different solutions with high osmotic potential so that pre-germinative metabolic activities proceed, while radicle protrusion is prevented and then seeds are dried back to the original moisture level. Harris et al., (2007) reported that seed priming led to better establishment, growth, earlier flowering, increase seed tolerance to adverse environment and greater yield in maize. The beneficial effects of seed priming have been demonstrated for many field crops such as wheat, sweet corn, mung bean, barley, lentil, cucumber etc. (Sadeghian and Yavari, 2004). Rehman et al., (2011) reported that seed priming is a cost effective technology that can enhance early crop growth leading to earlier and more uniform stand with yield associated benefits in many field crops including oilseeds. Various seed priming techniques have been developed which include hydro-priming, halo-priming, osmopriming and hormonal priming. Priming 
applications contribute to significant improvement in seed germination and seedling growth in vegetables (Dursun and Ekinci, 2010; Korkmaz, 2005; Korkmaz and Pill, 2003) and some field crops (Yari et al., 2010; Sağlam et al., 2010; Dezfuli et al., 2008; Ghassemi-Golezani et al., 2008; Sadeghi et al., 2011; Saeidi et al., 2008 and Elkoca et al., 2007).

\section{Types of seed priming}

Heydecker (1973) used different terms depending upon the method adopted for priming, namely;

\section{Hydropriming}

Hydropriming is the simplest method of seed priming, which relies on seed soaking in pure water and re-drying to original moisture content prior to sowing. Hydro-priming plays an important role in the seed germination, radical and plumule emergence in different crop species under saline and non-saline conditions and also have beneficial effect on enzyme activity required for rapid germination.

Beneficial effect of hydropriming on seed germination and seedling growth under both optimal and stress conditions, in various crop plants such as chickpea, maize, rice mung bean and capsicum has been observed (Rahman et al., 2011; Goswami et al., 2013; Posmyk and Janas, 2007 and Patade et al., 2012).

Harris (2006) has reported improvement in seed yield in various crops at farmer's field by seed priming with water. Caseiro et al., 2004 found that hydro-priming was the most effective method for improving seed germination of onion, especially when the seeds were hydrated for $96 \mathrm{hr}$ compared to 48 $\mathrm{hr}$. The main disadvantage of hydropriming is uncontrolled water uptake by seeds.

\section{Osmopriming}

Osmo-priming technique refers to soaking of seeds for a certain period in solution of sugar, PEG etc followed by air drying before sowing. Osmo-priming not only improves seed germination but also enhance crop performance under non saline or saline conditions. Salehzade et al., (2009) conducted a study to enhance germination and seedling growth of wheat seeds using osmo-priming treatments. Seeds were osmo-primed with PEG-8000 solution for 12 hours. Osmopriming treatments improved the seedling stand establishment parameters. Shorrocks (1997) reported that priming with boric acid showed stimulatory and inhibitory effect on different crops plants. In papaya species the priming with boron increased the growth of all plants.

\section{Halopriming}

Halo-priming refers to soaking of seeds in solution of inorganic salts i.e., $\mathrm{NaCl}, \mathrm{KNO}_{3}$, $\mathrm{CaCl}_{2}$ and $\mathrm{CaSO}_{4}$ etc. A number of studies have shown a significant improvement in seed germination, seedling emergence and establishment and final crop yield in salt affected soil in response to halo-priming. Priming with $\mathrm{NaCl}$ and $\mathrm{KCl}$ was helpful in removing the deleterious effects of salts (Iqbal et al., 2006). In sorghum seeds soaked in $\mathrm{CaCl}_{2}$ or $\mathrm{KNO}_{3}$ solution increased the activity of total amylase and proteases in germinating seeds under salt stress (Kadiri and Hussaini, 1999).

\section{Biopriming}

Biopriming involves seed imbibition together with bacterial inoculation of seed (Callan et al., 1990). As other priming method, this treatment increases rate and uniformity of germination, but additionally protects seeds against the soil and seed-borne pathogens. It 
was found that biopriming is a much more effective approach to disease management than other techniques such as pelleting and film coating (Muller and Berg, 2008). Nowadays, the use of biopriming with plant growth-promoting bacteria (PGPB) as an integral component of agricultural practices (Gulick et al., 2012; Timmusk et al., 2014). In pearl millet, biopriming with Pseudomonas fluorescens isolates enhanced plant growth and resistance against downy mildew disease (Raj et al., 2004). Biopriming with rhizobacteria improved germination parameters of radish seeds under saline conditions (Kaymak et al., 2009).

\section{Solid matric priming}

Solid matrix priming (SMP, matriconditioning), in which water uptake by seeds is controlled. During solid matrix priming, seeds are mixed and incubated with wet solid water carrier for a certain period. Afterward, seeds are separated from matrix, rinsed, and back-dried. The use of solid medium allows seeds to hydrate slowly and simulates natural imbibition process occurring in the soil (McDonald, 2000). To successfully accomplish SMP, materials utilized as matrices should possess specific physical and chemical features such as low matrix potential, minimal water solubility, high water holding capacity and surface area, no toxicity to seeds, and ability to adhere to seed surface.

Solid matrix priming enhanced field performance of carrot as well as improved germination and seed vigour. More recently published data demonstrated that solid matrix priming with Trichoderma viride improved seedling emergence and yield of okra under low temperatures (Pandita et al., 2010) (Table 1).

Table.1 The required soaking time for different crops and the percentage of benefits observed after soaking the crops

\begin{tabular}{|c|c|c|c|}
\hline Crop & $\begin{array}{c}\text { Soaking } \\
\text { (hour) }\end{array}$ & $\begin{array}{c}\text { Countries } \\
\text { Largest yield benefits } \\
\text { consistently observed to } \\
\text { date (\%) }\end{array}$ \\
\hline A. Crop in which benefits have been repeatedly confirmed \\
\hline Wheat & 12 & India, Nepal, Pakistan & 37 \\
\hline Barley & 12 & Pakistan & 40 \\
\hline Upland rice & $12-18$ & India, Nigeria, Sierra, Leone, Gambia, \\
& & Cameriin & 70 \\
\hline Maize & $12-18$ & India, Nepal, Pakistan Zimbabwe & 22 \\
\hline Sorghum & 10 & Pakistan Zimbabwe & 31 \\
\hline Pearl millet & 10 & Pakistan & 56 \\
\hline Chickpea & 8 & Bangladesh, India, Nepal, Pakistan & 50 \\
\hline Mungbean & 8 & Pakistan & 206 \\
\hline Finger millet & 8 & India & 15 \\
\hline
\end{tabular}

Importance of seed priming in agriculture

\section{Germination}

Primed seeds enhanced uniform seedling emergence which may contribute to regular crop establishment, it often exhibit an increased germination rate and greater germination uniformity. Priming may also induce structural and ultrastructural modifications that could facilitate subsequent water uptake and attenuate initial differences 
between the seeds in terms of imbibition, thus resulting in a more uniform germination (Galhaut et al., 2014). In mung bean plants, a faster seedling establishment resulting from priming may contribute to a total increase in yield up to $45 \%$ (Rashid et al., 2004).

Priming-induced increase in germination may be associated to a change in plant hormone biosynthesis and signaling. Priming has been reported to increase gibberellins (GA)/abscisic acid (ABA) ratio (El-Arab et al., 2006) and this may be a direct consequence of a priming impact in gene expression pattern (Schwember et al., 2010). Ethylene also directly influences germination speed and percentage. Increase in ethylene production during priming may promote endo- $\beta$-mannase activity facilitating endosperm weakening and post-priming germination (Chen and Arora, 2013).

\section{Plant growth and development}

Plants produced from primed seeds often exhibit a faster growth than unprimed ones. The beneficial impact of priming on plant growth may be due to an improved nutrient use efficiency allowing a higher relative growth rate (Muhammad et al., 2015). A higher growth of seedlings issued from primed seeds may also be analyzed in relation to a direct impact of pretreatment on cell cycle regulation and cell elongation processes (Chen and Arora, 2013). The growth parameters of chickpea were significantly affected by seed priming (Gupta and Singh, 2012)

\section{Yield}

Yield increase may also result from a higher plant density observed as a consequence of priming-induced increase in germination percentage (Murungu et al., 2004 and Harris et al., 2004). Seed priming treatment resulted in increased crop growth rate in treated sets which encouraged deposition of more photoassimilates in key plant parts, greatly affecting the final yield (Srivastava and Bose, 2012). Highest grain yield of Pusa Basmati 1121 was obtained with hydro-priming at 60 $\mathrm{kg} / \mathrm{ha}$ of $\mathrm{N}$ application applied in 3 splits (Mahajan et al., 2011). Binang et al., (2012) also demonstrated that priming had a significant effect on the number of tillers, number of fertile panicles, and consequently grain yield of new NERICA rice varieties.

\section{Storability}

Seed storage would increase the metabolic activity of the seeds and consequently decrease the reserve substance content and reduced the dry material weight of the seed (Bewley and black, 1982). Tarquis and Bradford (1992) reported that hydropriming of lettuce seeds improved seed germination rate decreased the longevity faster than the nonprime control seed under controlled deterioration conditions even under mild storage conditions $\left(45^{\circ} \mathrm{C}\right.$ and $50 \%$ relative humidity). Mohan Kumar and Manonmani (2011) reported that haloprimed in sunflower seeds with $2 \% \mathrm{KNO}_{3}$ maintain the storage potential by recording maximum germination and field emergence after six month of storage than unprimed seed.

It is concluded that in most agricultural and horticultural crops, seed priming led to improvement in germination and seedling establishment. It is the best solution of germination related problems especially when crops are grown under unfavourable conditions. Many priming techniques have been evolved which are being utilized in many crops now days. It enhances the percentage of germination and seedling emergence which ensures proper crop stand establishment under a wide range of environmental conditions. 


\section{References}

Bewley, J.D. and Black, M. 1982. Physiology and Biochemistry of seed in Relation to Germination. In: Viability, Dormance and environmental control. Springer-Verlag, UK, pp: 268-273.

Binang, W.B., Shiyam, J.Q. and Ntia, J.D. 2012. Effect of seed priming method on agronomic performances and cost effectiveness of rainfed, dry-seeded NERICA rice. Research Journal of Seed Science. 5:136-143.

Callan, N.W., Marthre, D.E. and Miller, J.B. 1990. Bio-priming seed treatment for biological control of Pythium ultimum preemergence damping-off in sh-2 sweet corn. Plant Disease. 74: 368-372.

Caseiro, R., Bennett, M.A. and Marcos, Filho. J. 2004. Comparison of three priming techniques for onion seed lots differing in initial seed quality. Seed Sci Tech. 32: 365-375.

Chen, K. and Arora, R. 2013.Priming memory invokes seed stress-tolerance. Environmental and Experimental Botany. 94:33-45.

Dezfuli, P.M., Sharif-zadeh, F. and Janmohammadi. M. 2008. Influence of Priming Techniques on Seed Germination Behaviour of Maize Inbred Lines (Zea mays L.). ARPN Journal of Agricultural and Biological Science. 3(3): 22-25.

Dursun, A. and Ekinci. M. 2010. Effects on different priming treatments and priming durations on germination percentage of parsley (Petroselinum crispum L.) seeds. Agricultural Sciences. 1(1): 17-23.

El-Araby, M.M., Moustafa, S.M.A., Ismail, A.I. and Hegazi, A.Z.A. 2006. Hormones and phenol levels during germination and osmopriming of tomato seeds, and associated variation in protein patterns and anatomical seed features. Acta Agronomica Hungarica. 54:441-458

Elkoca, E., Haliloglu, K., Eşitken, A. and Ercişli, S. 2007. Hydro- and osmopriming improve chickpea germination. Acta
Agriculture Scandinavica Section B-Soil and Plant Science. 57: 193-200.

Galhaut, L., Lespinay, A., Walker, D.J., Bernal, M.P., Correal, E. and Lutts, S. 2014. Seed priming of Trifolium repens L. improved germination and early seedling growth on heavy metal contaminated soil. Water Air Soil Pollution. 225:1-15.

Ghassemi-Golezani, K., Aliloo, A.A., Valizadeh, M.and Moghaddam, M. 2008. Effects of Different Priming Techniques on Seed Invigoration and Seedling Establishment of lentil (Lens culinaris Medik.). Journal of Food, Agriculture and Environment. 6(2): 222-226.

Goswami, A., Banerjee, R. and Raha, S. 2013. Drought resistance in rice seedlings conferred by seed priming: role of the anti-oxidant defense mechanisms. Protoplasma. 250:1115-29.

Gulick, B.R. 2012. Plant Growth-Promoting Bacteria: Mechanisms and Applications. Hindawi Publishing Corporation, Scientifica. Pp.1-15.

Gupta, V. and Singh, M. 2012. Effect of seed priming and fungicide treatment on chickpea (Cicer arietinum) sown at different sowing depths in kandi belt of low altitude sub-tropical zone of Jammu. Applied Bio Res. 14: 187-92.

Harris, D. 2006. 'On-farm' seed priming. A key technology to improve the livelihoods of resource-poor farmers in marginal environments (extended version). DFID/PSP information booklet, CAZS Natural Resources, University of Wales, Bangor, UK.

Harris, D., Rashid, A., Hollington, A., Jasi, L and Riches, C. 2007. Prospects of improving maize yield with on farm seed priming. In: Rajbhandari, N.P. and Ransom, J.K. 'Sustainable Maize Production Systems for Nepal'. NARC and CIMMYT, Kathmandu, pp: 180-185.

Heydecker, W. 1973. Accelerated germination by osmotic seed treatment. Nature. 246: 42-44.

Iqbal, M., Ashraf, M., Jamil, A. and Rehmaan, S. 2006. Does seed priming induce 
changes in the level of some endogenous plant hormones in hexaploid wheat plant under salt stress. J Int Pl Bio. 48181-89.

Kadiri, M. and Hussaini, M. A. 1999. Effect of hardening pre-treatment on vegetative growth, enzyme activities and yield of Pennisetum americanum and Sorghum bicolour L. Global J Pure Appl Sci. 5: 179-183.

Kaymak, H.C., Guvenc, I., Yarali, F. and Donmez, M.F. 2009. The effects of biopriming with PGPR on germination of radish (Raphanus sativus L.) seeds under saline conditions. Turkish Journal of Agriculture and Forestry. 33:173-179.

Korkmaz, A. 2005. Inclusion of Acetyl Salicylic Acid and Methyl Jasmonate into the Priming Solution Improves Lowtemperature Germination and Emergence of Sweet Pepper. Hort Science. 40(1): 197-200.

Korkrmaz, A. and Pill, W.G. 2003. The Effect of Different Priming Treatments and Storage Conditions on Germination Performance of Lettuce Seeds. Eur. J. Hort. Sci. 68(6): 260-265.

Mahajan, G., Singh, J. and Sharma, N. 2011. Enhancing the performance of direct seeded basmati rice through seed priming and nitrogen management. Indian J Agron (oryza) 48: 380-82.

McDonald, M. B. 2000. Seed Priming. In: Seed Technology and its Biological Basis, Black, M. and Bewley, J. D. (Eds.). Shefield Academic Press, Shefield, UK, pp:287-325.

Mohan Kumar, G. and V. Manonmani, 2011. Standardisation of seed priming and its influence on biochemical changes in germination of sunflower seeds. Proceeding of National Seed Congress held at January 25-26, Pune, India, pp:209-212.

Muhammad, I., Kolla, M., Volker, R. and Günter, N. 2015. Impact of nutrient seed priming on germination, seedling development, nutritional status and grain yield of maize. Journal of Plant Nutrition. 38:1803-1821.
Müller, H. and Berg, G. 2008. Impact of formulation procedures on the effect of the biocontrol agent Serratia plymuthica HRO-C48 on Verticillium wilt in oilseed rape. BioControl. 53: 305-316.

Murungu, F.S., Chiduza, C., Nyamugafa, P., Clarck, L.J., Whalley, W.R. and FinchSavage, W.E. 2004. Effect of on-farm seed priming on consecutive daily sowing occasions on the emergence and growth of maize in semi-arid Zimbabwe. Field Crop Research. 89:49-57.

Pandita, V.K., Anand, A., Nagarajan, S., Seth, R. and Sinha, S.N. 2010. Solid matrix priming improves seed emergence and crop performance in okra. Seed Science and Technology. 38:665-674.

Patade, V.Y., Khatri, D., Manoj, K., Kumari, M. and Ahmed, Z. 2012. Cold tolerance in thiourea primed capsicum seedlings is associated with transcript regulation of stress responsive genes. Molecular Biology Reports. 39:10603-10613.

Posmyk, M.M. and Janas, K.M. 2007. Effects of seed hydropriming in presence of exogenous proline on chilling injury limitation in Vigna radiata L. seedlings. Acta Physiologiae Plantarum. 29:509-517

Rahman, M.M., Ahammad, K.U. and Alam, M.M. 2011. Effect of soaking condition and temperature on imbibition rate of maize and chickpea seeds. Research Journal of Seed Science. 4:117-124.

Raj, N.S., Shetty, N.P. and Shetty, H.S. 2004. Seed bio-priming with Pseudomonas fluorescens isolates enhances growth of pearl millet plants and induces resistance against downy mildew. International Journal of Pest Management. 50:41-48.

Rashid, A., Harris, D., Hollington, P. and Ali, S. 2004. On-farm seed priming reduces yield losses of mungbean (Vigna radiata) associated with mungbean yellow mosaic virus in the North West Frontier Province of Pakistan. Crop Protection. 23:11191124.

Rehman, H. U., Maqsood, S., Basra, A. and Farooq, M. 2011. Field appraisal of seed priming to improve the growth, yield and 
quality of direct seeded rice. Turk J Agric. 35: 357-65.

Sadeghi, H., Khazaei, F., Yari, L. and Sheidaei, S. 2011. Effect of Seed Osmopriming on Seed Germination Behavior and Vigor of Soybean (Glycine max L.). ARPN Journal of Agricultural and Biological Science. 6(1): 39-43.

Sadeghian, S. Y. and Yavari, N. (2004). Effect of water deficient stress on germination and early seedling growth in sugar beet. $J$ Agron Crop Sci. 190: 138-44.

Saeidi, M.R., Abdolghaium, A., Hassanzadeh, M., Rouhi, A. and Nikzad, P. 2008. Investigation of Seed Priming on Some aspects of Different Canola Cultivars. $J$. of Food, Agriculture and Env. 6(2): 188191.

Sağlam, S., Day, S., Kaya, G. and Gürbüz, A. 2010. Hydropriming Increases Germination of Lentil (Lens culinaris Medik.) under Water Stress. Not Sci. Biol. 2(2): 103-106.

Salehzade, H., Shishvan, M. I., Ghiyasi, M., Forouzin, F. and Siyahjani, A.A. 2009. Effect of seed priming on germination and seedling growth of wheat [Triticum aestivum (L).]. Res J Biol. Sci. 4: 629-31.

Schwember, A.R. and Bradford, K.J. 2010. A genetic locus and gene expression pattern associated with the priming effect on lettuce seed germination at elevated temperature. Plant Molecular Biology. 73: 105-118.

Shorrocks, V.M. 1997. The occurrence and correction of boron deficiency. Pl Soil. 193: $121-48$.

Srivastava, A. K. and Bose, B. 2012. Effect of nitrate seed priming on phenology, growth rate and yield attributes in rice (Oryza sativa L.). Vegetos. 25: 174-81.

Tarquis, A.M. and Bradford, K.J. 1992. Prehydration and priming treatment that advance germination also increase the rate of deterioration of lettuce seed. $J$. Exp. Bot. 43: 307-317.

Timmusk, S, Abd El-Daim, I.A., Copolovici, L., Tanilas, T., Kannaste, A., Behers, L., Nevo, E., Seisenbaeva, G., Stenstrom, E. and Niinemets, U. 2014. Droughttolerance of wheat improved by rhizosphere bacteria from harsh environments: enhanced biomass production and reduced emissions of stress volatiles. PLoS One. 9 (5):e96086.

Yari L., Aghaalikani M. and Khazaei, F. 2010. Effect of Seed Priming Duration and Temperature on Seed Germination Behaviour of Bread Wheat (Triticum aestivum L.) ARPN Journal of Agricultural and Biological Science. 5(1): $1-6$.

\section{How to cite this article:}

Mampi Debbarma and Shubhashree Priyadarshinee Das. 2017. Priming of Seed: Enhancing Growth and Development. Int.J.Curr.Microbiol.App.Sci. 6(12): 2390-2396.

doi: https://doi.org/10.20546/ijcmas.2017.612.276 